\title{
A Review of Computational Tools for Designing Drugs Used by General Practitioners
}

\section{Dipika Rungta*}

Birla Institute of Technology, Mesra, Ranchi, India

*Corresponding author: Dipika Rungta, Birla Institute of Technology, Mesra, Ranchi, 835215, India, Tel: 9835027742; E-mail: dipikarungta1991@gmail.com

Received date: December 10, 2014; Accepted date: December 18, 2014; Published date: December 30, 2014

Copyright: (c) 2014 Rungta D. This is an open-access article distributed under the terms of the Creative Commons Attribution License, which permits unrestricted use, distribution, and reproduction in any medium, provided the original author and source are credited.

\begin{abstract}
The presented review is based on the survey of various computational tools that are being used to design novel compounds commonly referred as drugs. These drugs are commonly used in general practice by licensed professionals including physicians, chemists, pharmacists, doctors, etc. These drugs include drugs for depression, stress, fever, etc.
\end{abstract}

Keywords: General practitioners; General practice; Computational tools

\section{Introduction}

The process of designing new molecules and compounds in order to get new biological, chemical and physical properties is a very long and laborious process. Drug is a key molecule used to inhibit a particular molecular pathway or for the enhancement in the synthesis of biological macromolecules. In general practice, the general practitioners [1] use several kinds of drugs to deal with the common diseases and health problems. These drugs sometimes get resistant to the human body. In order to avoid antibiotic resistance, scientists have been trying to develop newly designed drugs with more efficiency. Designing a drug molecule against any disease needs the knowledge of both the protein which is responsible for its occurrence together with the molecular pathway of its transmission in the human body. This knowledge is further implemented and used in order to get a compound or molecule against the target protein. Traditionally, the process of drug designing was very time consuming, tedious and cost effective. Previously, many molecules and compounds were needed to be synthesized and tested in different organisms to obtain a suitable class of compound that can have the desired profile for a drug with lesser side effects. The random screening of a large number of compounds and a chance discovery of a lead compound out of them is a typical process that takes approximately 14 years and over $\$ 800$ million [2]. It was length expensive and intellectually inelegant.

Computer aided drug design (CADD) is a widely-used term that represents computational tools and servers used for the modeling, analysis and storage of compounds [2]. It includes development of databases for the study of chemical interaction relationships, computer programs for designing compounds with interesting physicochemical properties, as well as tools for the identification of potential lead candidates before they are synthesized and tested in wet laboratories. CADD is broadly categorized into two groups- a) Ligand based drug design and, b) Structure based drug design. In the ligand based drug design, a model, say, QSAR model, of the target protein is built based on the knowledge of the ligand that binds to it, and this model is then used to design new molecules that interact with the target protein for their inhibitory or stimulatory activity [3]. On contrary, structure based drug design has the knowledge of the structure of target protein obtained through X-ray Crystallography and NMR spectroscopy [4]. This knowledge is used to design a ligand that can have the best binding affinity with the target and can be further used as a lead compound against the protein.

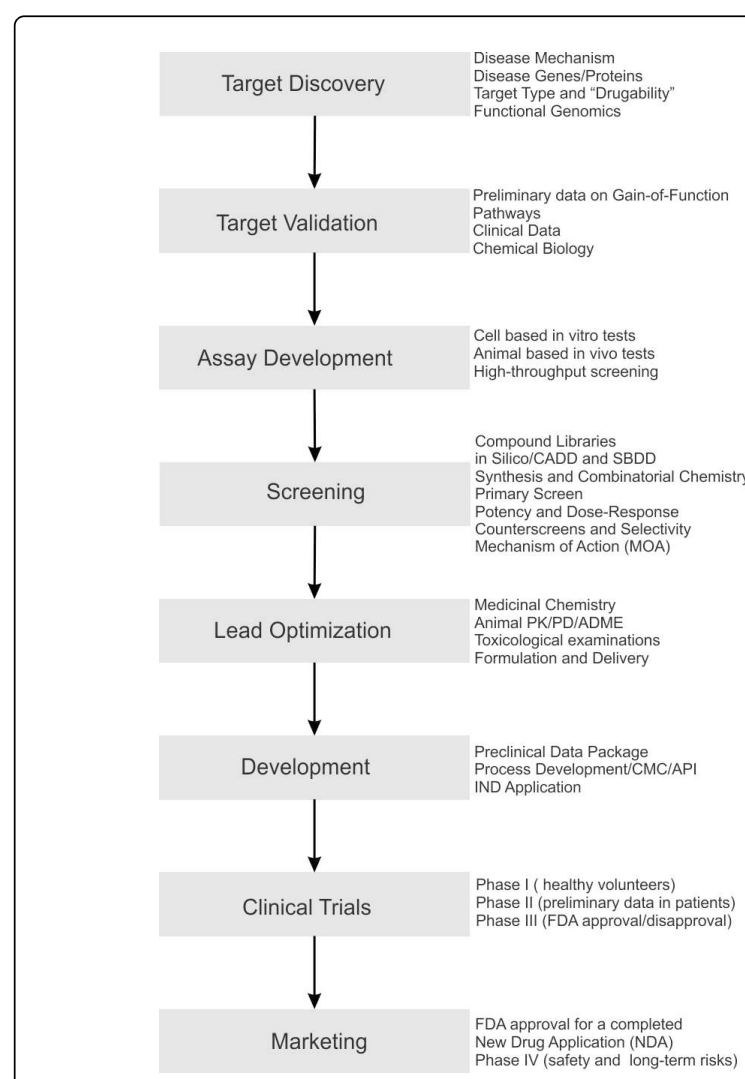

Figure 1: The general procedure used in drug designing used in its development and marketing. 


\section{Molecular Modeling}

Molecular modeling is a computational technique to design the structure of novel compounds. It mimics the behaviour of molecules to design a newer molecule with better activity [4]. It is used in the fields of computational chemistry, drug design, computational biology and materials science for studying molecular systems ranging from small chemical systems to large biological molecules [5]. The common feature of molecular modeling techniques is the atomistic level description of the molecular systems. Molecular modeling has become an important technique in the study of various biological pathways that include protein folding, protein stability, enzyme catalysis and identification of novel proteins, and other macromolecules [6]. There are various modeling softwares available online that have allowed the researchers to create biological models and modify them by the addition or removal of moieties and change in the covalent bonds, bond angles, interactions, etc as per their need. Table 1 is a list of modeling softwares that are generally used in the modeling of 3D structures of proteins.

\begin{tabular}{|c|c|c|c|}
\hline S.No. & $\begin{array}{l}\text { Name of } \\
\text { Software }\end{array}$ & Description & Reference \\
\hline 1. & $\begin{array}{l}\text { DeepView-Swiss } \\
\text { PdbViewer }\end{array}$ & $\begin{array}{l}\text { It provides an user friendly } \\
\text { interface allowing to } \\
\text { analyze and model proteins }\end{array}$ & Johansson [7] \\
\hline 2. & CCP4 & $\begin{array}{l}\text { It is used for } \\
\text { macromolecular structure } \\
\text { determination }\end{array}$ & Winn et al. [8] \\
\hline 3. & Modeller & $\begin{array}{l}\text { It involves homology or } \\
\text { comparative modeling of } \\
\text { protein three-dimensional } \\
\text { structures }\end{array}$ & Eswar et al. [9] \\
\hline 4. & UCSF Chimera & $\begin{array}{l}\text { It is a modeling program } \\
\text { for interactive visualization } \\
\text { and analysis of molecular } \\
\text { structures }\end{array}$ & Lin et al. [10] \\
\hline 5. & Abalone & $\begin{array}{l}\text { It is a modeling program } \\
\text { focused on molecular } \\
\text { dynamics of biopolymers }\end{array}$ & $\begin{array}{l}\text { http:// } \\
\text { www.biomolecular- } \\
\text { modeling.com/ } \\
\text { Abalone/ }\end{array}$ \\
\hline 6. & Tinker & $\begin{array}{l}\text { It is a package for } \\
\text { molecular mechanics and } \\
\text { dynamics, with some } \\
\text { special features for } \\
\text { biopolymers }\end{array}$ & $\begin{array}{l}\text { http:// } \\
\text { dasher.wustl.edu/ffe/ }\end{array}$ \\
\hline 7. & Geno3D & $\begin{array}{l}\text { Geno3D is an automatic } \\
\text { web server for protein } \\
\text { molecular modelling. }\end{array}$ & Combet et al. [11] \\
\hline
\end{tabular}

Table 1: List of Molecular modeling softwares.

\section{Virtual Screening}

Virtual screening is a computational technique that is used in drug designing to search libraries of small molecules in order to identify the structures of those compounds that may act as lead compounds with maximum affinity for a drug target that may be a protein or an enzyme [12]. Its basic aim is to score, rank and filter a set of chemical structures using one or more computational databases or other techniques. Virtual screening has been defined as the "automatically evaluating very large libraries of compounds" using computer programs [13]. This method is accurate and allows the researchers to get an authenticated structure that may be used as a drug after further validations. Due to this, virtual screening has become an integral part of the drug discovery process [14].

\section{Protein-Ligand Docking}

Protein-ligand docking methods are used to recognize most favourable positions, orientations and conformations of a ligand or small molecule in a protein (http://www.intechopen.com/books/ protein engineering-technology-and-application/protein-protein-andprotein-ligand-docking). As, most of the diseases occurring in human body is due to the improper functioning of enzyme or a protein, this method is widely used during virtual screening of a lead compound for a target protein. It is also used to predict the position of any ligand that is already bound to the target in order to calculate and identify the active site. There are various softwares that enable the researchers to do the protein-ligand docking. Table 2 is the list of molecular docking softwares.

\begin{tabular}{|c|c|c|c|}
\hline $\begin{array}{l}\text { S.N } \\
\text { o. }\end{array}$ & $\begin{array}{l}\text { Name of } \\
\text { Software }\end{array}$ & Description & Reference \\
\hline 1. & Autodock & $\begin{array}{l}\text { It involves automated docking of } \\
\text { flexible ligands to macromolecules }\end{array}$ & $\begin{array}{l}\text { (http:// } \\
\text { autodock.scripps.e } \\
\text { du/). }\end{array}$ \\
\hline 2. & $\begin{array}{l}\text { CombiBUIL } \\
\text { D }\end{array}$ & $\begin{array}{l}\text { It is a structure-based drug design } \\
\text { program that is created to aid the } \\
\text { design of combinatorial libraries }\end{array}$ & sandia.gov \\
\hline 3. & DockVision & $\begin{array}{l}\text { It carries Monte Carlo, Genetic } \\
\text { Algorithm, and database screening } \\
\text { docking algorithms }\end{array}$ & $\begin{array}{l}\text { http:// } \\
\text { www.dockvision.co } \\
\text { m/ }\end{array}$ \\
\hline 4. & $\begin{array}{l}\text { QM } \\
\text { Polarized } \\
\text { Ligand } \\
\text { Docking }\end{array}$ & $\begin{array}{l}\text { It carries the function of both Glide } \\
\text { and Q-Site applications of } \\
\text { Schrodinger Suit }\end{array}$ & Varga et al. [15] \\
\hline 5. & GOLD & $\begin{array}{l}\text { It identifies correct binding modes of } \\
\text { the active target molecules }\end{array}$ & $\begin{array}{l}\text { http:// } \\
\text { www.ccdc.cam.ac. } \\
\text { uk/Solutions/ } \\
\text { GoldSuite/Pages/ } \\
\text { GOLD.aspx }\end{array}$ \\
\hline 6. & $\begin{array}{l}\text { Docking } \\
\text { Server }\end{array}$ & $\begin{array}{l}\text { It provides a web-based, easy to use } \\
\text { interface for the molecular docking of } \\
\text { protein and ligand }\end{array}$ & Bikadi et al. [16] \\
\hline 7. & SwissDock & $\begin{array}{l}\text { It is a protein ligand server that is } \\
\text { accessed via ExPASy }\end{array}$ & $\begin{array}{l}\text { http:// } \\
\text { www.swissdock.ch } \\
\text { / }\end{array}$ \\
\hline 8. & Click2Drug & It is accessed via ExPASy server & $\begin{array}{l}\text { http:// } \\
\text { www.click2drug.or } \\
\text { g/ }\end{array}$ \\
\hline
\end{tabular}

Table 2: List of Molecular docking softwares.

In the present era, two docking softwares namely Autodock 4.2 and Glide are very frequently used for CADD study. Glide 4.0 XP scoring function has been developed and implemented as the docking protocol to estimate protein-ligand binding affinities [17]. On the other hand, Autodock is reported to have utility in analysis of covalently-bound ligands, using both a grid-based docking method and a modification of the flexible side chain technique [18]. 


\section{Simulation}

MD Simulation is a computational method that is used to examine the dynamicity of the biological macromolecules. It calculates the time dependent behavior of a molecular system. MD simulation provides detailed information on the fluctuations and conformational changes of proteins and nucleic acids. These methods are now routinely used to inspect the structure, dynamics and thermodynamics of biological macromolecules and their complexes. They are also used in the determination of structures from X-ray crystallography and from NMR experiments. Molecular dynamics simulations allow the study of interactions occurring between different macromolecules during various cellular life processes (http://www.ch.embnet.org/ MD_tutorial/pages/MD.Part1.html) together with the analysis of biological processes occurring in a living system. These include, for example,

\section{Protein stability \\ Conformational changes}

Protein folding

Molecular recognition: proteins, DNA, membranes, complexes

Ion transport in biological systems

One of the most commonly used MD simulation softwares is Gromacs [19]. It takes input files in PDB format and produces trajectory files that carry the information of each and every conformational change that would have occurred on each atom during simulation. By the use of several commands, it has permitted the researchers to study the stability and minimization of energy of proteins as well as protein bound complexes.

\section{Conclusion}

Nowadays, various new drug entities have been designed used for general practices. These drugs include antihypertensive agents, antiinflammatory agents, drugs for ulcer therapy, immunosuppressive agents, etc [20]. These drugs carry several side effects and reactions to the human body. In order to overcome them, bioinformaticians have tried to design newer and more efficient drugs with lesser side effects. For the drug designing, the tools discussed are playing a major role in the enhancement of these modified drugs development.

\section{References}

1. Cox P (2013) The Busy General Practitioner's Reference Guide to Increasing Physical Activity Levels in the British Population and Associated Benefits/Risks: A Review of the Literature. Journal of General Practice 1: 1 .

2. Song CM, Lim SJ, Tong JC (2009) Recent advances in computer-aided drug design. Brief Bioinform 10: 579-591.
3. Guner, Osman F (2000) Pharmacophore Perception, Development, and use in Drug Design. La Jolla, Calif: International University Line.

4. Leach AR (2001) Molecular Modelling: Principles and Applications.

5. Omidi Y (2011) Integration of Molecular, Cellular and Translational Researches in BioImpacts. Bioimpacts 1: 3-5.

6. Ramachandran KI, Deepa G, Namboori K (2008) Computational Chemistry and Molecular Modeling Principles and Applications. Springer-Verlag GmbH.

7. Johansson MU, Zoete V, Michielin O, Guex N (2012) Defining and searching for structural motifs using DeepView/Swiss-PdbViewer. BMC Bioinformatics 13: 173.

8. Winn MD, Ballard CC, Cowtan KD, Dodson EJ, Emsley P, et al. (2011) Overview of the CCP4 suite and current developments. Acta Crystallogr D Biol Crystallogr 67: 235-242.

9. Eswar N, Marti-Renom MA, Webb B, Madhusudhan MS, Eramian D, et al. (2006) Comparative Protein Structure Modeling With MODELLER. Current Protocols in Bioinformatics 15: 5.6.1-5.6.30

10. Lin J, Okada K, Raytchev M, Smith MC, Nicastro D (2014) Structural mechanism of the dynein power stroke. Nat Cell Biol 16: 479-485.

11. Combet C, Jambon M, Deléage G, Geourjon C (2002) Geno3D: automatic comparative molecular modelling of protein. Bioinformatics 18: 213-214.

12. Rester U (2008) From virtuality to reality - Virtual screening in lead discovery and lead optimization: a medicinal chemistry perspective. Curr Opin Drug Discov Devel 11: 559-568.

13. Walters WP, Stahl MT, Murcko MA (1998) Virtual screening -an overview. Drug Discov Today 3: 160-178.

14. Malcolm JM, Zhaowen L, Xuliang J (2007) Virtual screening in drug discovery. Drug Discovery Research. New Frontiers in the Post-Genomic Era. 63-88.

15. Varga N, Sutkeviciute I, Guzzi C, McGeagh J, Petit-Haertlein I, et al. (2013). Selective Targeting of Dendritic Cell-Specific Intercellular Adhesion Molecule-3-Grabbing Nonintegrin (DC-SIGN) with MannoseBased Glycomimetics: Synthesis and Interaction Studies of Bis(benzylamide). Chem Eur J 19: 4786-4797.

16. Bikadi Z, Hazai E (2009) Application of the PM6 semi-empirical method to modeling proteins enhances docking accuracy of AutoDock. J Cheminform 1: 15.

17. Friesner RA, Murphy RB, Repasky MP, Frye LL, Greenwood JR, et al. (2006) Extra precision glide: docking and scoring incorporating a model of hydrophobic enclosure for protein-ligand complexes. J Med Chem 49: 6177-6196.

18. Morris GM, Huey R, Lindstrom W, Sanner MF, Belew RK, et al. (2009) AutoDock4 and AutoDockTools4: Automated docking with selective receptor flexibility. J Comput Chem 30: 2785-2791.

19. Alder BJ, Wainwright TE (1957). J Chem Phys 27: 1208.

20. Wipperich T, Sponder M, Stütz L, Demir D, Kaider A, et al. (2014) Influence of Migration Status and Gender on Awareness of Cardiovascular Risk Factors and Cardiovascular Health in a Group of Turkish Immigrants andIndigenous Austrians. Journal of General Practice 2:5. 